\title{
THE STATE OF THE ART OF GENDERED ENERGY INNOVATIONS: A STRUCTURED LITERATURE REVIEW
}

\author{
S. van der Merwe ${ }^{1 *}$, I. de Kock ${ }^{1} \&$ J.K. Musango ${ }^{2}$
}

\section{ARTICLE INFO}

\section{Article details \\ Presented at the $31^{\text {st }}$ annual conference of the Southern African Institute for Industrial Engineering (SAllE), held virtually from 5-7 October 2020. \\ Available online $\quad 11$ Nov 2020 \\ Contact details \\ Corresponding author \\ 20080204@sun.ac.za \\ Author affiliations \\ 1 Department of Industrial Engineering, Stellenbosch \\ University, South Africa \\ 2 School of Public Leadership, Stellenbosch University, South Africa}

ORCID ${ }^{\circledR}$ identifiers

S. van der Merwe

https://orcid.org/0000-0002-2030-3979

I. de Kock

https://orcid.org/0000-0003-4136-7418

J.K. Musango

https://orcid.org/0000-0001-9635-0002

\section{DOI}

http: / /dx.doi.org/10.7166/31-3-2427

\section{ABSTRACT}

The impact of restricted access to sustainable energy is the worst in vulnerable urban poor areas, and so an alternative approach to energy innovations is needed. To explore the possibilities for energy innovations, gender needs to be taken into account. This is especially relevant in the sub-Saharan African context, as most households are female-headed. This paper aims to explore the current state of gendered energy innovations by using a multivocal approach; it thus focuses on the existing body of knowledge at the gender-energy interface. The study is conducted in two parts: first, 'state of the art' is conceptualised using a multilevel approach; second, a structured literature review on gendered energy innovations is conducted in light of the structured understanding of 'state of the art'. There is definitely room for new innovations to use gender as a strategy for solving energy security problems in urban poor environments.

\section{OPSOMMING}

Die impak van beperkte toegang tot volhoubare energiebronne is ergste in kwesbare arm stedelike gebiede, en gevolglik is ' $n$ alternatiewe aanslag tot energie-innovasie, nodig. Om die moontlikhede vir energie-innovasies te ondersoek, moet geslag in ag geneem word. Dit is veral relevant in subSahara Afrika aangesien die meeste huishoudings in hierdie konteks ' $n$ vrou as hoof het. Hierdie artikel ondersoek die huidige toestand van geslag ten opsigte van energie-innovasies deur middel van ' $n$ veelduidige benadering. Dit fokus dus op die bestaande navorsing in die veld waar geslag en energie raakpunte het. Die studie is tweeledig: eerstens, word die konsep, 'state of the art', deur middel van ' $n$ multivlak-benadering gedefinieer; tweedens word ' $n$ gestruktureerde literatuurstudie rakende geslag in die konteks van energie-innovasies gedoen aan die hand van 'n gestruktureerde verstaan van 'state of the art'. Daar is beslis potensiaal vir nuwe energie-innovasies, wat geslag as 'n oplossingstrategie gebruik om probleme rakende energie sekuriteit in arm stedelike gebiede op te los.

\section{INTRODUCTION}

Recent studies have found a high correlation between the sustained and inclusive social and economic development of a country and the energy consumption of its inhabitants [1]-[3]. One could therefore argue that access to energy plays a vital role in the pace of a country's development [4]. Research on energy transitions in the developing world is critical, as the International Energy Agency predicts that two-thirds of the world's energy demands will come from the developing world over the next two decades [5]. Various scholars are beginning to assert that climate, energy, equality, and gender are forming inextricable integrations [6]-[10]. These integrated complexities of the fields of energy access, energy justice, and energy security need to be explored in-depth, as the gendered nature of energy transitions is often implicit and unexplored [9]; but studies have proven significant correlations between energy security and gender equality [1], [4], [11]-[13].

This growing recognition of the connections between gender inequality and energy justice is amplified in vulnerable communities, such as those in urban poor environments in sub-Saharan Africa, which typically exhibit high numbers of female-headed households [14]. The argument, therefore, is that energy 
inequalities and the lack of access to sustainable energy practices are disproportionately affecting women in the developing world $[3,14,15]$.

While there is recognition of the need for an understanding of gendered energy transitions, limited studies describe its current state (the 'state of the art'). A broad multi-disciplinary approach is needed to solve the problem at hand, as the concept of 'energy justice' has gained prominence in the energy-related fields of the social sciences and the humanities in recent years [3]. The field of gendered energy innovations combines the technical research of applied science and the narrative critique of social science.

\subsection{Rationale for this research}

The focus of this research is justified by the apparent lack of deep engagement with knowledge on the influence of gender inclusion in the energy-technology field. The attention of academics, social scientists, and policy-makers has shifted towards sustainability in their efforts to shape cities so that they improve the life of urban dwellers [17]. However, there still seems to be a lack of knowledge at the gendersustainability interface. This points to a potential naïveté in the body of knowledge about that fact that sustainable energy security neglects important gendered considerations.

This paper therefore seeks to inform the discourse on how gender can be used as a strategy to deal with energy (in)justice and (in)equality under the umbrella of energy (in)security. Although energy justice is not the sole focus of this study (but rather energy access, energy security, and energy innovations), justice is integrated into almost every part of energy in the developing world, as marginalised groups (such as women, or those living in urban poor environments) tend to be disproportionately affected by energy injustices [22]-[24]. Multiple societal problems exist, and there are various strategies to solve these. This paper will explore how gender can be used as a problem-solving strategy to approach the societal issue of energy security in the context of urban poor environments.

Scholars [3] have recently conducted a structured review of energy justice frameworks aimed at developing countries. Similar to their work, this paper will be a structured review of the available literature, as the few energy justice reviews that have been done in the past have been predominantly narrative and nonsystematic.

\subsection{Objectives}

The aim of this paper is to explore the status of the field of gendered energy innovations - i.e., the 'state of the art'. In doing so, the contribution of this paper can be seen as part of the knowledge-brokering process in the novel field of gendered energy innovations. In order to work towards this aim, the objectives of this paper can be categorised into main objectives and sub-objectives. The objectives are: (i) to investigate suitable constructs that may facilitate the definition of the state of the art of energy-transitionrelated phenomena that include gender as a key focus, in a structured way - i.e., exploring the relevant phases, levels, and concepts that are necessary to synthesise a structured understanding of the state of the art; (ii) to undertake a structured literature review to explore the literature in the field of gendered energy technology innovations - i.e. first engagements with the literature by investigation of the search results using different search functions; (iii) to combine the efforts of objective (i) and (ii) into a summarising table to synthesise a structured understanding of the state of the art of gendered energy technology innovations in urban poor environments; and finally (iv) to conclude the paper by providing some considerations for future work.

\subsection{Background}

\subsubsection{Underlying environmental challenges}

In recent population projections, the global urban population is expected to increase by a staggering 34 per cent by 2050 [21]. What is more alarming is that Africa is expected to see a 154 per cent increase in urban population size by 2050 [22].

Accompanying urbanisation is the increased transition to energy technology innovations and the need for energy access [23]. However, the continuous transition to more sustainable communities is underwritten by social and, ironically, environmental injustices that are rarely acknowledged. In fact, without careful attention being paid to them, sustainable transitions that do not consider social aspects such as gender may paradoxically contribute to environmental decay and worsen existing gender inequalities [1].

The need to address this issue is well-recognised by the global humanitarian community: hence the inclusion of gender equality in the United Nation's (UN) Sustainable Development Goals (SDG(s)) as well as the UN's 
Call to Action for gender equality and women's economic empowerment [24]. Sustainability challenges therefore call for fundamental systemic transformations [25].

\subsubsection{Gender in context}

While acknowledging that gender studies, especially in the past decade, has become more extensive than ever before, the focus of this study is simplified to define gender purely as male and female, as is often done in empirical studies and literature works. This study is therefore confined to studying gender in binary terms - that is, with an emphasis on women and men respectively. This study will not delve deeply into the anthropological side of gender studies, but rather focus more on defining the levels of discourse where gender and energy meet. The scope therefore excludes a deep analysis of gender studies and the differences between sex and gender.

In the last couple of decades, gender has become an important theme in energy research [13]. Gender serves as a tool for understanding diversity and inequality, especially in relation to energy poverty in developing countries and sustainable transition projects [26].

In the literature, gender was found to play a significant role in entrepreneurship and access to electricity [14,15], economic growth [29], and energy policy and organisational practices [32]. The interconnectedness of the spheres in which gender plays a significant role reinforces the fact that excluding gendered considerations in innovation could be detrimental to other sustainability efforts.

\section{RESEARCH APPROACH}

A structured approach is followed, as it has been proven that a systematic approach is effective in understanding the scientific field of gendered energy innovations and energy justice research [20]. Structured systematic change is essential when one seeks to establish long-term sustainable gender mainstreaming at the core of problem-solving, as in the case of gender mainstreaming for energy security [33].

The approach of this study is twofold:

1. First, this paper investigates how best to conceptualise the state of the art of phenomena in the field of energy transitions in a structured way, considering how various levels and phases can be included in a study - i.e., how to define what a structured definition of the state of the art entails; and then

2. The second part is aimed at determining the status of the field of gendered energy innovations i.e., engaging with the literature by investigating that which is concerned with energy, gender, and innovations in the context of urban poor environments - i.e., to determine what the status of the field of gendered energy innovations is.

From these efforts, an amalgamated understanding of the nexus of the two aforementioned bodies of literature should be formed.

In the remaining sections of this paper, Part I will be discussed first (including its search strategy and associated search results), followed by Part II and its respective research strategy. Finally, these two distinct parts will be combined to synthesise the structured understanding of the state of the art of gendered energy innovations.

\section{PART I - CREATING A STRUCTURED UNDERSTANDING OF 'STATE OF THE ART'}

Given that the field of gendered energy innovations is a novel concept, important information is available in 'grey' literature that has not been formally published. Excluding that source might result in neglecting an important bridge of information between what is documented in the academic literature and what is observed on less formal publication platforms. Scholars [34] use an alternative research protocol - that of a multivocal literature review - to include grey literature as complementary to academic publications. Grey literature played a significant role in Part I of the research process.

To understand how a phenomenon should be defined in a structured way, it is necessary to understand the intended purpose. In other words, one needs to ask: "Why is it necessary to understand the state of the art?" In the case of this study, the answer is that gender inclusion needs to become common/mainstream practice in the energy transitions field if one wants to make a sustainable impact to bring about change. 
So the mainstreaming process (sometimes referred to as institutionalisation or normalisation) needs to be explored $[29,31,32]$. In addition to the need for mainstreaming, it is said that norms play an important role in governance arrangements - both in the regulation of companies and in the provision of public goods [37]. As energy security is a global theme that is included in global narratives, such as SDG 7 [24], it is worth classifying the phases of institutionalisation for energy. Google's general search engine was used to search information on the process of mainstreaming/institutionalisation.

\subsection{The phases of institutionalisation}

Drawing upon corporate norms (such as corporate social responsibility), the climate change literature, domestication theories, and generic institutional transformation - in all four of which the link to gendered energy innovations is clear - a deeper understanding is achieved in defining the phases of institutionalisation.

The phases of institutionalisation identified in the literature for each concept are summarised in Table 1.

Table 1: Comparative table of the phases of institutionalisation

\begin{tabular}{|l|l|}
\hline Phenomena & Phases identified \\
\hline $\begin{array}{l}\text { Corporate social } \\
\text { responsibility }\end{array}$ & Norm emergence; norm cascade; norm internalisation [38] \\
\hline Climate change literature & $\begin{array}{l}\text { Scientific consensus; political action; financial resources; institutionalisation in } \\
\text { multilateral organisations [39] }\end{array}$ \\
\hline Domestication theories & Appropriation; objectification; incorporation; conversion [40] \\
\hline $\begin{array}{l}\text { Institutional } \\
\text { transformation }\end{array}$ & Introduction; implementation; consolidation [36] \\
\hline
\end{tabular}

After consulting with subject matter experts, comparing similarities and differences between the phenomena and gendered energy innovations, and considering how the phases can best represent a new amalgamation of the phases that are the most relevant to gendered energy innovations, newly identified phases of institutionalisation of gendered energy innovations were synthesised: concept appropriation; norm emergence; norm development; and internalisation.

In addition to the phases of institutionalisation, certain principles form an integral part of the gender mainstreaming process. These vary from equal access and the utilisation of all services to equal involvement in decision-making and equal treatment in the steering process of organisations [35]. The complexity of gendered energy innovations and the mainstreaming of gender for energy security thus call for another layer of structure, such as using a multilevel approach to determine the various levels in the energy narrative.

\subsection{Multilevel approach to contextual factors}

Several studies in the field of energy justice, energy access, and the transitions literature had randomly addressed multiple levels on which gender is included (or should be included) in the energy narrative, even though a structured multilevel approach was not necessarily followed in any of the studied cases. Some examples are discussed below, and compared in Table 2.

Informed by the work of academici [37,38,39] Lacey-Barnacle, Robison and Foulds [3] created a sustainability framework for discussions on energy justice. The levels identified (institutional, economic, environmental, and socio-cultural) were all considered for inclusion in this study. Another energy justice framework is aimed at facilitating a deeper analysis of energy justice on the political, societal, and environmental levels [41].

Unpacking the social and political issues surrounding energy access is inevitable in the energy narrative [6]. Other vital themes in the aforementioned study on energy research are institutional practices and the social aspects of marginalised communities in developing countries. In a systematic review [42], several domains of research have been identified, varying from fuel characteristics, household characteristics, financial aspects, legislation, and standards to programme mechanisms. Finally, it has been found that, in developing countries, what seems to be general indicators of the adoption potential of households of alternative energy technologies include social, demographic, institutional, environmental, technical, and economic indicators [43].

In an effort to combine the input of the studies under consideration, Table 2 is synthesised to summarise the findings. 
Table 2: Comparative table of the levels of discourse in the energy narrative

\begin{tabular}{|l|l|}
\hline Studies & Levels of discourse \\
\hline$[3]$ & Institutional; economic; environmental; socio-cultural \\
\hline$[41]$ & Political; societal; environmental \\
\hline$[6]$ & Social; political; institutional \\
\hline$[42]$ & Fuel characteristics; household; financial; legislation/standards; programmes \\
\hline$[43]$ & Social; demographic; institutional; environmental; technical; economic \\
\hline
\end{tabular}

Given that two of the abovementioned sources were systematic reviews $[3,43]$, this comparative table of the levels of discourse is even more far-reaching and inclusive. After conglomerating some of the mentioned domains/levels, those that proved dominant or that encapsulated more than one aspect at a specific level of discourse, were selected. The levels are: policy level; organisational/institutional level, technological/innovations level, programme/project level, household level, and cultural level.

Policy
Organisational
Technological
Programme
Household
Cultural

Figure 1: Non-binary spectrum of multiple levels

An important consideration is the non-binary nature of the identified levels. Even though the levels are distinct for the purpose of gathering information in a structured way, they should be seen as if on a spectrum rather than on hierarchical 'levels'. The levels are all integrated, and all influence one another in some way. Some scholars [45] agree that, without holistic perspectives on the interdependencies of the impact of social practices, it is impossible to overcome barriers, and social change is made unsustainable [2].

Note that the position of the respective levels on this spectrum refers to the extent to which they influence the levels in their closest proximity. For example, cultural aspects manifest themselves in households, which in turn usually have direct contact with energy programmes/projects implemented by organisations using technologies, all of which are governed by political pursuits of energy justice and sustainable practices. However, this does not mean that one level can only influence its adjacent levels directly. The relation and impact of the levels upon one another can reach beyond just that. For example: the activities on the cultural level can extend beyond just the households and have a direct effect elsewhere. One could therefore even argue that the non-binary system is also non-linear. If one wants the most sustainable and authentic change to take place, the most logical approach would be to follow bottom-up principles owing to the interconnected nature of all of the levels.

\section{PART II - DETERMINING THE STATUS OF THE FIELD OF GENDERED ENERGY INNOVATIONS}

\subsection{Research protocol}

Part II of the study was conducted in alignment with the PRISMA methodology of doing a structured literature review [46]. As mentioned, the research field of gendered energy innovations is novel; so using the multivocal approach is appropriate. Grey literature is included in this structured literature review by referring to a general internet search engine, Google, as the source of literature besides what has been obtained though the academic literature database Scopus. However, formally published academic documents were predominantly used in Part II. Regarding information sources, the academic database Scopus was used to search for formally published academic literature in the field of gendered energy innovations.

A brief outline of the methodology of this section is as follows: first, the data collection points are determined, followed by the eligibility criteria that will depict which studies will be included in the search. 
Subsequently the search functions that were used to engage with the literature are investigated; and finally the risk of bias across the various studies in this search is addressed.

\subsection{Data collection points}

Given the qualitative nature of this literature review, data collection items are better defined as the 'information points' for which a clearer understanding is sought. The authors therefore scrutinised the available literature and collected data specifically on the levels identified in Section 3.2.

\subsection{Inclusion/exclusion criteria}

The inclusion criteria's filtering can be seen as twofold, creating two 'pools' or bodies of literature. Only documents that ultimately 'pass' the second round of inclusion criteria are included in the study. The first layer of filtering includes all bodies of literature that:

i) are in English;

ii) consider energy in the context of innovation and technology (in other words, excluding the energy aspects related to medicine and biology); and

iii) were conducted in developed and developing countries, given that the concepts that are discussed in the document are relevant to gendered energy innovations.

The rationale behind criterion (iii) is as follows: even though it would make sense to include only studies in urban poor contexts, or a developing country, or a rural environment, after some consideration the authors decided that this would exclude literature with valuable information. It is worth mentioning that many similarities were found in the behavioural elements of women's attitudes to energy and sustainability, regardless of their demographic or sociographic circumstances.

As a second layer of filtering for the inclusion criteria, the paper under consideration had to elaborate extensively on at least one of the identified data collection points (as identified in section 3.2). This is done to avoid an ineffective reading of bodies of literature.

The exclusion criteria can be derived from the inclusion criteria. Simply put, all bodies of literature that do not pass both layers of filtering for inclusion are excluded. This is especially important for documents pertaining to the second layer of filtering so as to do research as effectively as possible and not do redundant reading.

\subsection{Search functions}

The first engagement with the literature was by means of a rapid review search. Where the title did not give sufficient insights into whether one of the inclusion criteria in the first filtering layer would be met, the abstract was read.

Upon searching the literature using the radicals of "energy" and "gender OR gendered" and "technolog*" and "Multilevel OR MLA", only one document was found and included in the first pool of documents. However, it was discarded after failing to meet the second layer of inclusion criteria. The reason for the inclusion of "Multilevel OR MLA" as a search term was to determine whether there are other studies that scrutinise the existing body of literature to define the current status of the field of gendered energy innovations.

The next search function was (energy AND technolog*) AND (gender OR gendered) AND (policy OR institution OR project OR economic OR household), which yielded 147 documents. After initial screening of the documents, the search function was adapted once again, and the following was added to it: AND NOT (medical OR nuclear OR identity). This time the search yielded 103 documents, of which 43 met both rounds of inclusion criteria and were successfully included in this study.

\subsection{Risk of bias}

Even though the focus of this paper is on urban poor environments, the authors deliberately decided still to include studies that dealt with all energy-related issues in the developing world. This helped to avoid the risk of bias across studies, since the problems women face are usually universal, but with some definite contextual factors in the developing world. Familiarising oneself with some of the issues that women in the developed world face (regarding energy security) might offer another point of view, and would highlight the similarities and contrasts in the issues in the distinctively different socio-economic contexts. 
After carefully learning from the literature that met the eligibility criteria, knowledge was gained on each of the data collection points by means of deductive content analysis.

\subsection{Policy level}

Many authors are convinced that the multifaceted justice implications of energy poverty have the most impactful implications on a legal and political level [3]. What's complex about this level is that, in some cases, policy protects vulnerable and marginalised groups (such as women) from exploitation. However, in many cases, the gender dimension is largely absent in the technocratic description of sustainable transition [9]. Technocratic approaches, therefore, are too narrow for policy-making on complex sustainability issues involving high and divergent societal stakes and scientific uncertainties [8].

Studies have shown that policies aimed at reducing energy consumption have more influence on women than on men [47]. Still, the policy-making process is the mainstream pathway, and is primarily a male domain [9]. One case study revealed that policies in a specific developed country do not challenge the mainstream route of the energy fossil fuel regime, and does not make room for the complex inequalities to which women are subject [9]. The authors expressed the urgent need to address gender-based issues and gendered analysis in decision-making at governmental level. Another case study revealed that, in 2010, the Kenyan government set out new provisions for eradicating gender inequality in the light of their vision of becoming a newly industrialising country by 2030 [50]. However, Kenya still largely followed the unsustainable 'mainstream route' of using fossil fuels for energy production [9].

It was also found that a lack of willingness to include sustainable efforts in the energy narrative, especially at a state governance level, resulted in widespread corruption in government institutions [3]. Excluding gender from this narrative might result in the same effect, as the literature shows how gender considerations are increasingly seen as inextricable from sustainable efforts. Excluding gender might therefore result in corrupt government institutions [6,33].

\subsection{Organisational/company level}

Effective, accountable, and reliable organisations are paramount in the governance of energy transitions [3]. A qualitative study [45] of households found that, of the 13.4 per cent of respondents who indicated that they worked in the energy sector, only 26.5 per cent of them were women [2]. Women who work in the energy sector of the world usually hold technical jobs, and are largely unrepresented in the decisionmaking narrative, as they are excluded from leadership positions in large energy firms, especially in the developing world [9].

Organisations therefore have all the more reason to consider a more gendered approach to their business. The underrepresentation of female members on boards and in management groups of large energy companies therefore potentially has a negative effect on risk aversion and investments in renewable energy [52].

A case study of Kenya's mainstream energy pathways has found that, even though the legislation revised in 2013 included a considerably larger number of gender considerations than those revised in 2004, yet formal energy institutions in Kenya still had men with engineering backgrounds dominating the decision-making space, holding senior management positions [50],[9]. Women are to a large extent excluded in energy organisations, even though the intention seems different when considering the country's legislation. The discrepancy between what is intended and what is executed proves that some effort has been made to develop the norm of a more gender-equal organisational space, but that this concept is far from being internalised.

\subsection{Technology/innovations level}

The study of technology up to the 1980s was 'gender blind' [49] because technology was considered gender neutral. However, the establishment of feminist science, technology, and social studies questioned this perception in the 1990s [13]. Since then, technology has been increasingly seen not only as pragmatic, but also as playing a more critical role in the everyday lives of its users.

Transformative transition pathways involve a radical technological innovation, and the representation of all gender perspectives is becoming a new norm [9]. Men and women agree that energy technology has 
gendered perceptional differences [2]. The same study found that men are more drawn to the technological features, whereas women lean towards the environmental benefits that alternative energy holds for the planet [2].

A study in Bangladesh found that what influences the adoption of new energy technologies the most is the gender of the household head [54]. The same study investigated the factors that influence the adoption and use of new energy technologies in urban poor settings in South Africa. Even though gender has a significant impact on the adoption of energy technology, it is socio-economic phenomena that have an impact on its use. This just confirms the interconnectedness of gender inclusion across all levels of the nonbinary level spectrum in Error! Reference source not found..

\subsection{Programme/project level}

A search of the literature found that a large majority of the results were based on case studies before and after the implementation of some intervention or energy-related project. What is evident is that the projects are successful in their aim of seeking gender equality by uplifting women. These programmes range from implementing improved cooking stoves and educational projects for girls in the STEM field to helping women become energy entrepreneurs [52]. Actors are galvanising ambitions further with successful grassroots initiatives and social movements. The rise of renewable energy projects has brought forth a social agenda in the transition, bringing principal elements of justice directly into interplay with social change and gender equality [8].

Although many successful projects are aimed at mainstreaming gender, empowering women, and including them in energy narratives, some projects do fail. It is important to investigate why these projects fail and to learn from the mistakes, in order to avoid them in future. A specific case study in rural India yielded interesting results: in spite of massive efforts to promote the adoption of improved cooking stoves over many decades, studies suggest that the women simply do not want stoves that differ from their traditional way of cooking. In essence, the rural women targeted by 'development experts' have different priorities, and seem not to share the same vision of a better life as those promoting the improved cooking stoves [55]. This confirms again the interconnectedness of all the levels on the spectrum (Figure 1).

\subsection{Household level}

The gendered division of household labour tends to assign women the primary responsibility for most activities [56]. Women disproportionately bear the burden of household activities in urban poor environments. New energy technology innovations might therefore have significant impacts on women, lift the time burden they face in their homes, and open up new opportunities for education or other economic development. Improved household energy initiatives are thus instrumental in this gendered energy transition [57].

A study in rural South African homes found a significant positive correlation $(p<0.01)$ between the willingness to adopt a new energy technology affecting the household, and the gender of the household head [4].

In a systematic review [42], an intensive study was done to determine which factors affected household decision-making to adopt or reject clean cooking technologies. Some gender-related findings have been reported in respect to the time drudgery women face, as well as opportunity cost [42]. Therefore it is safe to conclude that, once the household activity burden has been eased for women, a multitude of other opportunities will be presented, possibly leading to time invested in economic activity, education, and development.

Including gendered energy considerations at household level has not been sufficient so far. This is consistent with a study that found that clean energy fuels can help women by reducing the time spent gathering cooking fuels and introducing more efficient and faster cooking practices. The women in the studies argued that the time freed up by more efficient and sustainable household activities would allow them time to generate income and to socialise with other community members [58].

From the literature, therefore, it is clear that everyday practices in the home and ideas on home and housing are highly gendered. The extent to which this knowledge has been implemented is unclear. Questions about household energy-consuming practices by the different genders need to be investigated. 


\subsection{Cultural level}

Transitions toward a low-carbon future are not only technical and economic, but also deeply social and cultural [9]. Understanding gender relations on a cultural level is important for the success of a sustainable transition in the energy system. Excluding knowledge of gender in the uptake of new technologies may hinder the implementation of sustainability measures [13]. A study in Pakistan found that the most significant predictors of alternative energy technology adoption included social dynamics and gender roles [43].

Referring back to the case study of the failed implementation of cooking stoves in rural India, it is important to understand that some of the existing energy technologies (as inefficient or unsustainable as they may seem) serve multiple cultural and traditional purposes too. Most of the time, existing energy practices are deeply embedded in the culture of a community. New sustainable technologies that might seem attractive could be discarded and rejected by the community if the historical and cultural context is not taken into account. An important part of ensuring that energy transitions happen effectively is considering these underlying cultural and social aspects that influence people's decisions to invest in new energy technologies that are more sustainable [2].

\section{DISCUSSION OF RESULTS}

\subsection{Summary of results}

Summarising the information from Sections 3, 4 and 5 into a single table is useful for understanding clearly the state of the art of gendered energy innovations, and how the developing world is doing in the process of institutionalisation. Conceptualising the interface between institutionalisation and the multilevel approach, while taking the results of the structured literature review into account, is best displayed by Table 3.

Table 3: Summarising the state of the art of gendered energy innovations

\begin{tabular}{|l|c|c|c|c|}
\hline & Concept appropriation & Norm emergence & Norm development & Internalisation \\
\hline Policy & $\mathrm{X}$ & $\mathrm{X}$ & - & - \\
\hline Organisation & - & $\mathrm{X}$ & - & - \\
\hline Technology & $\mathrm{X}$ & - & - & - \\
\hline Programme & - & - & $\mathrm{X}$ & $\mathrm{X}$ \\
\hline Household & $\mathrm{X}$ & $\mathrm{X}$ & - & - \\
\hline Cultural & $\mathrm{X}$ & - & - & - \\
\hline
\end{tabular}

Much work is still needed in order fully to institutionalise gendered energy innovations. All in all, the programme level seem to be the most fruitful for bringing about sustainable change, and serves as the intersection between the grassroots level and the more strategic high-level policy level.

\subsection{Recommendations}

There is clearly a strong connection between gender inequalities and energy injustice. Regarding the way forward and recommendations for future work, what role the decentralisation of energy power plays in marginalised communities (such as those in urban poor environments) should be investigated. This would provide even more evidence for energy and gender scholars to combine efforts and work in developing world contexts in a cross-disciplinary way.

\section{CONCLUSION}

This paper endeavoured to formulate a structured understanding of the state of the art of gendered energy innovations. This was done, first, by exploring how the state of the art can be structured in terms of phases of institutionalisation (concept appropriation, norm emergence, norm development, and internalisation). Second, the paper explored the levels at which the energy security discourse is taking place (at the policy, organisational, technology, programme, household, and cultural levels). Third, the extent to which gender has been included in these debates was discussed.

Key findings include that the only level at which the institutionalisation process has reached the "norm development and 'internalisation' phases is the programme level. There is therefore still much room for innovations to identify the optimal ways in which the institutionalisation phases can be advanced on the 
other identified levels, or how the programme level's full potential can be harnessed to influence the adjacent levels (the technology and household levels) that should, in turn, have a direct positive effect on their own adjacent levels. There are certainly even more barriers to overcome in the pursuit of fair and sustainable energy access that have not been deeply explored in this study - for example, the fact that energy innovations rely heavily on policy analysis [13]. The exact implementation and transformation process could be interesting to look into in the future, as it links back to change management - another aspect that is highly complex in the context of energy security and its gendered implications. Energy can radically improve and transform lives if issues of access and gender justice are addressed $[3,58]$.

\section{ACKNOWLEDGEMENT}

This work is part of the GENs ${ }^{1}$ research group, and is based on research by the Africa-UK Trilateral Research Chair ID SARCI 18076349612, under the Newton Fund, with a National Research Foundation of South Africa partnership, grant number 120129.

\section{REFERENCES}

[1] Sovacool, B.K., Hook, A., Martiskainen, M., Brock, A. \& Turnheim, B. 2020. The decarbonisation divide: Contextualizing landscapes of low-carbon exploitation and toxicity in Africa. Global Environmental Change, 60(102028), pp. 1-19.

[2] Standal, K., Talevi, M. \& Westskog, H. 2019. Engaging men and women in energy production in Norway and the United Kingdom: The significance of social practices and gender relations. Energy Research and Social Science, 60(101338), pp. 1-9.

[3] Lacey-Barnacle, M., Robison, R. \& Foulds, C. 2020. Energy justice in the developing world: A review of theoretical frameworks, key research themes and policy implications. Energy and Sustainable Development, 55, pp. 122-138.

[4] Uhunamure, S.E., Nethengwe, N.S. \& Tinarwo, D. 2019. Correlating the factors influencing household decisions on adoption and utilisation of biogas technology in South Africa. Renewable and Sustainable Energy Reviews, 107, pp. 264-273.

[5] International Energy Agency. 2017. World energy outlook. [Online] Available at: https: / /www.iea.org/reports/world-energy-outlook-2017 [Accessed: 20-Apr-2020].

[6] Munro, P., Van der Horst, G. \& Healy, S. 2017. Energy justice for all? Rethinking sustainable development goal 7 through struggles over traditional energy practices in Sierra Leone. Energy Policy, 105, pp. 635-641.

[7] Jagoe, K., Rossanese, M., Charron, D., Rouse, J., Waweru, F., Waruguru, M.A., Delapena, S., Piedrahita, R., Livingston, K. \& Ipe, J. 2020. Sharing the burden: Shifts in family time use, agency and gender dynamics after introduction of new cooking stoves in rural Kenya. Energy Research and Social Science, 64, pp.1-15.

[8] Sorman, A.H., García-Muros, X., Pizarro-Irizar, C. \& González-Eguino, M. 2020. Lost (and found) in transition: Expert stakeholder insights on low-carbon energy transitions in Spain. Energy Research and Social Science, 64(101414), pp. 1-19.

[9] Lieu, J., Sorman, A.H., Johnson, O.W., Virla, L.D. \& Resurrección, B.P. 2020. Three sides to every story: Gender perspectives in energy transition pathways in Canada, Kenya and Spain. Energy Research and Social Science, 68(1), pp.1-13.

[10] Standal, K., Winther, T. \& Danielsen, K. 2018. Energy politics and gender. In Hancock, K.J. \& Allison, J.E. (eds) The Oxford Handbook of Energy Politics. New York: Oxford University Press, available online at https://global.oup.com/academic/product/the-oxford-handbook-of-energy-politics9780190861360 ?cc=us\&lang=en\&.

[11] Clancy, J.S. 2016. In the light of what we know: Gender and energy transformations. Enschede: Universiteit Twente.

[12] Pachauri, S. \& Rao, N. 2013. Gender impacts and determinants of energy poverty: Are we asking the right questions? Current Opinion in Environmental Sustainability, 5(2), pp. 205-215.

[13] Mechlenborg, M. \& Gram-Hanssen, K. 2020. Gendered homes in theories of practice: A framework for research in residential energy consumption. Energy Research and Social Science, 67, pp.1-9.

[14] Kovacic, Z., Musango, J.K., Ambole, L.A., Buyana, K., Smit, S., Anditi, C., Mwau, B., Ogot, M., Lwasa, S., Brent, A.C., Nsangi, G. \& Sseviiri, H. 2019. Interrogating differences: A comparative analysis of Africa's informal settlements. World Development, 122(1), pp. 614-627.

[15] Terry, G. 2009. No climate justice without gender justice: An overview of the issues. Gender Development, 17(1), pp. 5-18.

[16] Mendelsohn, R., Dinar, A. \& Williams, L. 2006. The distributional impact of climate change on rich and poor countries. Environmental Development Economics, 11(2), pp. 159-178.

Mainstreaming Gender for Energy Security in Poor Urban Environments (GENs) is an African-UK Trilateral Research Chair in Stellenbosch University, in collaboration with Brunel University London in the United Kingdom and the University of Nairobi in Kenya. This article forms part of one of the many knowledge-generation projects aimed at building the research capacity of GENs. GENs is devoted to exploring gendered innovations to achieve energy security in urban poor environments. Therefore, as this paper focuses on the state of the art, it provides the foundation for how gendered innovation are in an African context when dealing with energy insecurity challenges. 
[17] Pasqualetti, M.J. \& Sovacool, B.K. 2012. The importance of scale to energy security. Journal of Integrative Environmental Sciences, 9(3), pp. 167-180.

[18] Healy, N. \& Barry, J. 2017. Politicizing energy justice and energy system transitions: Fossil fuel divestment and a 'just transition'. Energy Policy, 108, pp. 451-459.

[19] Jenkins, K., McCauley, D., Heffron, R. \& Stephan, H. 2014. Energy justice, a whole systems approach. Queen's Political Review, 2(2), pp. 74-87.

[20] Jenkins, K., McCauley, D., Heffron, R., Stephan, H. \& Rehner, R. 2016. Energy justice: A conceptual review. Energy Research and Social Science, 11, pp. 174-182.

[21] Ritchie, H. \& Roser, M. 2019. Urbanization, our world in data. [Online] Available at: https: / /ourworldindata.org/urbanization [Accessed: 10-Jun-2020].

[22] Bai, X., McPhearson, T., Cleugh, H., Nagendra, H., Tong, X., Zhu, T. \& Zhu, Y.G. 2017. Linking urbanization and the environment: Conceptual and empirical advances. Annual Review of Environment and Resources, 42, pp. 215240.

[23] Currie, P.K. \& Musango, J.K. 2016. African urbanization: Assimilating urban metabolism into sustainability discourse and practice. Journal of Industrial Ecology, 21(5), pp. 1262-1276.

[24] UN Secretary-General. 2016. Leave no one behind: A call to action for gender equality and women's economic empowerment. Women's Economic Empowerment, 16(1), pp.1-14.

[25] Turnheim, B., Asquith, M. \& Geels, F.W. 2020. Making sustainability transitions research policy-relevant: Challenges at the science-policy interface. Environmental Innovation and Societal Transitions, 34, pp. 116-120.

[26] McDade S. \& Clancy, J. 2003. Energy for sustainable development. Energy Sustainability and Development, 7(3), pp. 3-7.

[27] Emmons Allison, J., McCrory, K. \& Oxnevad, I. 2019. Closing the renewable energy gender gap in the United States and Canada: The role of women's professional networking. Energy Research and Social Science, 55, pp. 3545.

[28] Osunmuyiwa, O. \& Ahlborg, H. 2019. Inclusiveness by design? Reviewing sustainable electricity access and entrepreneurship from a gender perspective. Energy Research and Social Science, 53, pp. 145-158.

[29] Listo, R. 2018. Gender myths in energy poverty literature: A critical discourse analysis. Energy Research and Social Science, 38, pp. 9-18.

[30] Winther, T., Ulsrud, K. \& Saini, A. 2018. Solar powered electricity access: Implications for women's empowerment in rural Kenya. Energy Research and Social Science, 44, pp. 61-74.

[31] De Groot, J., Mohlakoana, N., Knox, A. \& Bressers, H. 2017. Fuelling women's empowerment? An exploration of the linkages between gender, entrepreneurship and access to energy in the informal food sector. Energy Research and Social Science, 28, pp. 86-97.

[32] Fraune, C. 2016. The politics of speeches, votes, and deliberations: Gendered legislating and energy policy-making in Germany and the United States. Energy Research and Social Science, 19, pp. 134-141.

[33] Swedish Gender Mainstreaming Support Committee. 2007. Gender mainstreaming manual: A book of practical methods from the Swedish Gender Mainstreaming Support Committee (JämStöd). 15, Stockholm: Swedish Government Official Reports.

[34] Turetken, O., Garousi, V. \& Garossi, S. 2019. Maturity assessment and maturity models in healthcare: A multivocal literature review. Digital Health, 6, pp. 1-17.

[35] City of Vienna. 2020. The five principles of gender mainstreaming. Office for Gender Mainstreaming. [Online] Available: https://www.wien.gv.at/english/administration/gendermainstreaming/principles/five-principles.html [Accessed: 10-Jun-2020].

[36] European Institute for Gender Equality. 2016. Institutional transformation: Gender mainstreaming toolkit. Gender Institutional Transformation Guide. [Online] Available: https://eige.europa.eu/gendermainstreaming/toolkits/gender-institutional-transformation/step-8-introducing-gender-mainstreaming, [Accessed: 14-Jun-2020].

[37] Mühle, U. 2007. The foundations of legitimacy - Findings from the Institutionalisation of the UN Global Compact. Institute for World Society Studies, pp. 1-25.

[38] Sahlin-Andersson, K. 2006. Corporate social responsibility: A trend and a movement, but of what and for what? Corporate Government, 6, pp. 595-608.

[39] Hall, N. 2016. The institutionalisation of climate change in global politics. Environment, Climate Change and International Relations [Online] Available at: https://www.e-ir.info/2016/05/27/the-institutionalisation-ofclimate-change-in-global-politics/ [Accessed: 29-Apr-2020].

[40] Silverstone, R., Hirsch, E. \& Morely, D. 1992. Information and communication technologies and the moral economy of the household. New York. Routledge.

[41] Lappe-Osthege, T. \& Andreas, J.J. 2017. Energy justice and the legacy of conflict: Assessing the Kosovo C thermal power plant project. Energy Policy, 107, pp. 600-606.

[42] Puzzolo, E., Pope, D., Stanistreet, D., Rehfuess, E.A. \& Bruce, N.G. 2016. Clean fuels for resource-poor settings: A systematic review of barriers and enablers to adoption and sustained use. Environmental Research, 146, pp. 218234.

[43] Bekele, W. \& Drake, L. 2003. Soil and water conservation decision behaviour of subsistence farmers in the eastern highlands of Ethiopia: A case study of the Hunde-Lafto area. Ecological Economics, 46, pp. 437-451.

[44] Bell, S., Judson, E., Bulkeley, H., Powells, G., Capova, K. \& Lynch, D. 2015. Sociality and electricity in the United Kingdom: The influence of household dynamics on everyday consumption. Energy Research and Social Science, 9, pp. 98-106.

[45] Standal, K. \& Winther, T. 2016. Empowerment through energy? Impact of electricity on care work practices and gender relations. Forum for Development Studies, 43(1), pp. 27-45.

[46] Moher, D., Liberati, A., Tetzlaff, J. \& Altman, D. 2009. The PRISMA Statement. PLoS Med, 6(7), pp. 1-6. 
[47] Carlsson-Kanyama, A. \& Lindén, A.L. 2007. Energy efficiency in residences - Challenges for women and men in the North. Energy Policy, 35(4), pp. 2163-2172.

[48] Scott, J. \& Clery E. 2013. Gender roles and incomplete revolution. In Park, A., Bryson, C., Clery, E., Curtice, J. \& Phillips, M. (eds) British social attitudes: The 30th Report. London: NatCen Social Research, available online at: http: Ilwww.bsa30.natcen.ac.uk.

[49] Faulkner, W. 2001. The technology question in feminism: A view from feminist technology studies. Women's Studies International Forum, 24(1), pp. 79-95.

[50] Society for International Development. 2010. Kenya's vision 2030: An audit from an income and gender inequalities perspective. Society for International Development.

[51] Jasanoff, S. 2018. Just transitions: A humble approach to global energy futures. Energy Research and Social Science, 35, pp. 11-14.

[52] UNDP. 2006. ENERGIA factsheet. [Online] Available at: https://www.energia.org/cm2/wpcontent/uploads/2015/02/01.INSTITUTIONALISING_GENDER_MAINSTREAMING_PROCESSES_IN_ENERGY_ORGANISATIONS1.pdf [Accessed: 20-Mar2020].

[53] Sovacool, B.K. \& Hess, D.J. 2017. Ordering theories: Typologies and conceptual frameworks for sociotechnical change. Social Studies and Science, 47(5), pp. 703-750.

[54] Kabir, H., Yegbemey, R.N. \& Bauer, S. 2013. Factors determinant of biogas adoption in Bangladesh. Renewable and Sustainable Energy Reviews, 28, pp. 881-889.

[55] Khandelwal, M., Hill, M.E., Greenough, P., Anthony, J., Quill, M., Lindeman, M. \& Udaykumar, H.S. 2017. Why have improved cook-stove initiatives in India failed? World Development, 92, pp. 13-27.

[56] Bhattacharya, T. 2017. Social reproduction theory: Remapping class, recentering oppression. London: Pluto Press.

[57] Guruswamy, L. 2011. Energy poverty. Annual Review of Environment and Resources, 36, pp. 139-161.

[58] Otte, P. 2009. Cooking with the sun: An analysis of solar cooking in Tanzania, its adoption and impact on development. Trondheim: M.Phil in Development Studies, Norweigian University of Science and Technology. pp. 1-110.

[59] Damgaard, C., McCauley, D. \& Long, J. 2017. Assessing the energy injustice implications of bioenergy development in Nepal. Energy, Sustainability and Society, 7(8), p. 1-16.

[60] Inderberg, T.H., Tews, K. \& Turner, B. 2018. Is there a prosumer pathway? Exploring household solar energy development in Germany, Norway, and the United Kingdom. Energy Research and Social Science, 42, pp. 258-269. 